\begin{tabular}{|c|c|}
\hline Proceeding of the $9^{\text {th }}$ ICEE Conference 3-5 April 2018 & CEA \\
Military Technical College \\
Kobry El-Kobbah, \\
Cairo, Egypt
\end{tabular}

\title{
CEA-5
}

\section{Simulation of Ammonia Production from Synthesis Gas}

\author{
${ }^{1}$ Pr.Dr.Nabil Abdel El Moneim, ${ }^{2}$ Dr.Ibrahim Ismail, ${ }^{3}$ Nasser. M.M
}

\begin{abstract}
Ammonia is a compound of nitrogen and hydrogen with the formula $\mathrm{NH}_{3}$. It is a colorless gas with a characteristic pungent smell. Several processes have been invented for optimum production of ammonia. Now-a-days, Haber process is a mainly process for Ammonia production in which the reaction between nitrogen and hydrogen done in the presence of an iron catalyst to form ammonia. In our work, simulation of ammonia synthesis process is done on Aspen Hysys V8.8. By using $333.1 \mathrm{kmole} / \mathrm{h}$ of steams, 100 $\mathrm{kmole} / \mathrm{hr}$ of nitrogen, we have produced $74.62 \mathrm{kmole} / \mathrm{hr}$ ammonia. It has also been found that ammonia production increases with the rise of pressure \& mass flow of steam \& decrease of the temperature of the feed of nitrogen.
\end{abstract}

\section{Keywords:}

Ammonia, Simulation, Haber

1,2 Cairo University of Engineering

3. Egyptian Armed Force. 

Military Technical College
Kobry El-Kobbah, Cairo, Egypt

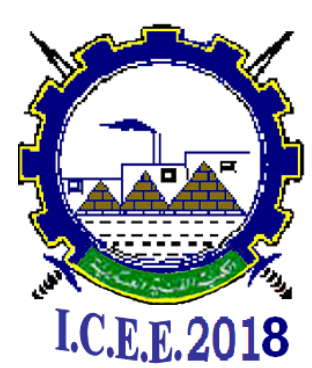

$9^{\text {th }}$ International Conference on

Chemical \& Environmental Engineering

3-5 April 2018

\section{Introduction}

Ammonia $\left(\mathrm{NH}_{3}\right)$ is one of the largest synthetic chemicals, produced in more than 80 countries. In fact, the synthesis of this world class commodity figures among the greatest achievements of industrial chemistry, after which important processes were developed such as methanol, oxo synthesis, Fischer - Tropsch Process and Reppe reactions.

Ammonia is basically produced by the reaction between nitrogen and hydrogen, in a 1:3 stoichiometric ratio. Its production routes are related to the hydrogen production method, being steam reforming the main one. Natural gas and naphtha are the most common hydrocarbon feeds used. Currently, most of the existing and almost all new steam reforming plants use natural gas for feedstock.

The most important note is that the production of Ammonia by steam reforming of natural gas is a somewhat clean operation with no significant environmental problems. On the other hand, the use of heavy feed stocks raises additional environmental issues related to, for instance, particulate emissions from solids handling of the feeds.

Hager (2007) approved that, the need for $\mathrm{NH}_{3}$ production from abundantly available resources such as natural gas and air came about from the vast population growth following in the wake of the industrial revolution in the 1800s. More mouths to feed demanded increased agricultural output and the answer to this was the large scale application of fertilizers.

Appl, M. (2006) explained that, feedstock for textiles, chemical products and explosives is some of applications of ammonia. Haber-Bosch process is used in most modern NH3 plants to produce ammonia from nitrogen and hydrogen which are obtained from air and (mainly) natural gas. These processes are operated with reactor temperatures of 400$500^{\circ} \mathrm{C}$ and pressures ranging from $100-200$ bar with considerable recycle of uncreated synthesis gas.

Williams, J. (2015) explained that, ammonia (NH3) is the most manufactured industrial chemical in the world per weight. $80 \%$ of the annual production of $160 \mathrm{M}$ tons (NH3) is applied as fertilizer either directly or as other ammonium based products. The huge scale and global knowledge of the Haber-Bosch process implies that the production process has to be optimal in order to remain competitive in a global and established yet fluctuating market. Estimates indicate that the global production capacity of ammonia will increase by more than $15 \%$ from 2015 to 2018 , possibly lowering the price of ammonia if the demand does not simultaneously grow at the same rate.

Computer based simulation has been popular now-a-days for different chemical engineering purposes. Though our task was to represent production of ammonia in renowned aspen HYSYS software, making some assumptions and using hypothetical reactors we have performed the ammonia production simulation. Though it does not give 
Military Technical College Kobry El-Kobbah, Cairo, Egypt

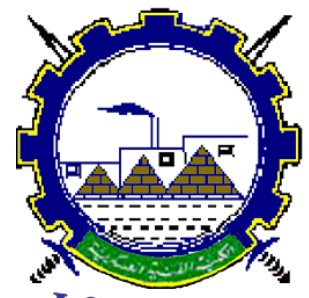

I.C.E.E.2018 $9^{\text {th }}$ International Conference on

Chemical \& Environmental

Engineering

3-5 April 2018

the real world performance or the real life production environment, but it can give relief from making wide range of experiment without making the small scale reactors or plant. The simulators are used to evaluate the steady state behavior of the process even though the mutual agreement about the reaction mechanism has not been established and thus the reliability of the results cannot be evaluated. The evaluation of the results will be carried out later when the applicability of the models found from the literature will be studied with the process data.

\section{Methodology}

Aspen hysys is the market leading process modeling solution that provides large economic benefits throughout the process engineering lifecycle \& enables companies to design and bring new plants \& reduce capital costs. The process of producing ammonia is simulated in Simulation software Aspen Hysys V 8.8. In this simulation we used PengRobinson model fits best to equilibrium process.

\subsection{Material \& Instrumentation:}

\begin{tabular}{|c|c|c|}
\hline \multirow{2}{*}{ Material } & Synthesis gas & Nitrogen \\
\cline { 2 - 3 } & Hydrogen & steam \\
\cline { 2 - 3 } & Synthesis gas & air \\
\hline \multirow{4}{*}{ Instrumentation } & Coolers & Absorbers \\
\cline { 2 - 3 } & separators & Reactors \\
\cline { 2 - 3 } & \multicolumn{2}{|c|}{ Mixers } \\
\hline Software & \multicolumn{2}{|c|}{ Aspen Hysys v 8.8 } \\
\hline
\end{tabular}

\subsection{Process Description:}

Ammonia is produced in a process known as the Haber process, in which nitrogen and hydrogen react in the presence of an iron catalyst to form ammonia. The hydrogen is formed by reacting natural gas and steam at high temperatures and the nitrogen is supplied from the air. Other gases (such as water and carbon dioxide) are removed from the gas stream and the nitrogen and hydrogen passed at high temperature and pressure to form the ammonia. 
Military Technical College Kobry El-Kobbah, Cairo, Egypt

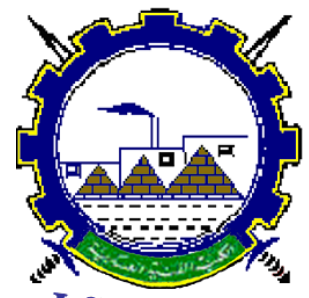

I.C.E.E.2018 $9^{\text {th }}$ International Conference on

Chemical \& Environmental Engineering

3-5 April 2018

\subsection{Hydrogen Production:}

The reaction of methane with water is used to produce the hydrogen. However, before doing this, all sulfurous compounds must be removed from the natural gas to prevent catalyst poisoning. These are removed by heating the gas to $400{ }^{\circ} \mathrm{C}$ and reacting it with zinc oxide:

$$
\mathrm{ZnO}+\mathrm{H}_{2} \mathrm{~S} \rightarrow \mathrm{ZnS}+\mathrm{H} 2 \mathrm{O}
$$

The gas is sent to the primary reformer for steam reforming, where superheated steam is fed into the reformer with the methane. The gas mixture heated with natural gas and purge gas to $770{ }^{\circ} \mathrm{C}$. At this temperature the methane converted to hydrogen, carbon dioxide and small quantities of carbon monoxide.

$$
\begin{aligned}
\mathrm{CH}_{4}+\mathrm{H}_{2} \mathrm{O} & \rightarrow \mathrm{CO}+3 \mathrm{H}_{2} \\
\mathrm{CH}_{4}+2 \mathrm{H}_{2} \mathrm{O} & \rightarrow \mathrm{CO}_{2}+4 \mathrm{H}_{2} \\
\mathrm{CO}+\mathrm{H}_{2} \mathrm{O} & \rightarrow \mathrm{CO}_{2}+\mathrm{H}_{2}
\end{aligned}
$$

\subsection{Removal of Carbon Monoxide:}

The water gas shift reaction $\left(\mathrm{CO}_{2}\right.$ absorber) is used to convert all carbon mono oxides to carbon dioxides according to the following reaction:

$$
\mathrm{CO}+\mathrm{H}_{2} \mathrm{O} \rightarrow \mathrm{CO}_{2}+\mathrm{H}_{2}
$$

\subsection{Removal of carbon dioxide:}

Removing carbon dioxide \& remaining of carbon monoxide is very essential step to prevent the poison of ammonia synthesis reaction.

\subsection{Ammonia Production:}

Ammonia produced due to catalytic reaction between hydrogen and nitrogen according to the following reaction:

$$
\mathrm{N}_{2}+\mathrm{H}_{2} \rightarrow \mathrm{NH}_{3}
$$

\section{Result and Discussions}

After performing the simulation we have found that the production of ammonia depends on different parameters of the process. So by controlling these parameters optimum ammonia production can be obtained.

From the simulation result we have observed the effect of several parameters on production. Those effects are described in below. 
Military Technical College

Kobry El-Kobbah,

Cairo, Egypt

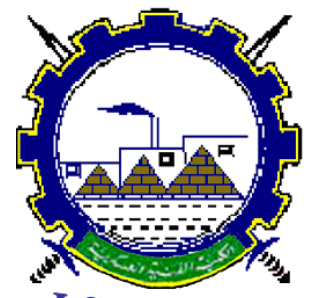

I.C.E.E.2018 $9^{\text {th }}$ International Conference on

Chemical \& Environmental

Engineering

3-5 April 2018

\subsection{Mass flow rate of steam}

The relation between Mass flow rate of steam \& mass flow rate of ammonia product can be easily realized from the plot given below:

From the plot, it is observed that the Mass flow rate of steam is directly proportional to ammonia product so the increases of mass flow rate of steam cause increase of the mass flow rate of produced ammonia.

\subsection{Pressure of steam}

This parameter can be easily observed from the plot given below:

From the plot, it is observed that the pressure of steam is directly proportional to ammonia product so the increases of pressure of steam cause increase of the mass flow rate of produced ammonia.

\subsection{Temperature of steam}

From the plot below, it is observed that the temperature of steam is inversely proportional to ammonia product so the increases of pressure of steam cause decrease of the mass flow rate of produced ammonia.

\subsection{Molar flow rate of Nitrogen}

From the plot below, it is observed that the Molar flow rate of Nitrogen is directly proportional to ammonia product so the Molar flow rate of Nitrogen cause increase of the mass flow rate of produced ammonia.

\subsection{Pressure of Nitrogen}

This parameter can be easily observed from the plot given below:

From the plot, it is observed that the Pressure of Nitrogen is directly proportional to ammonia product until the pressure reach to $2.754 * 10^{4} \mathrm{kpa}$ the relation is turned to inversely proportional so in this simulation the optimum operating pressure of Nitrogen is $2.754 * 10^{4} \mathrm{kpa}$.

\subsection{Temperature of Nitrogen:}

This parameter can be easily observed from the plot given below:

From the plot, it is observed that the temperature of Nitrogen is inversely proportional to ammonia product so the increases of temperature of Nitrogen cause decrease of the mass flow rate of produced ammonia. 
Military Technical College

Kobry El-Kobbah,

Cairo, Egypt

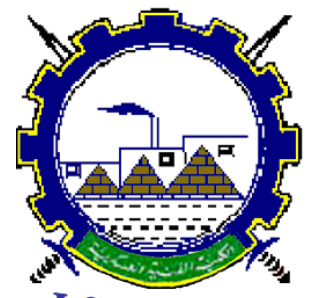

I.C.E.E.2018 $9^{\text {th }}$ International Conference

on

Chemical \& Environmental

Engineering

3-5 April 2018

\subsection{Temperature of feed of stream (1) on the duty of cooler (1):}

From the plot below, it is observed that the temperature of feed of stream (1) is directly proportional to duty of the cooler so the increases of temperature of feed of stream (1) cause increase of the duty of cooler.

\section{Conclusion}

Ammonia synthesis is an important chemical process. In our paper, we have generated data based on the simulation performed in HYSYS. This data can help us understand the process in different situation in industrial practice. By varying the different parameters in this simulation environment, the effects of these parameters on ammonia production are observed and the results are shown in graphical form. Using the plots, the optimum conditions for ammonia production can be easily found out.

\section{References}

[1] Amin, M. R., Sharear, S., Siddique, N., \& Islam, S. (2013). Simulation of Ammonia Synthesis. American Journal of Chemical Engineering, 1(3), 59-64.

[2] Appl, M. (2006). Ammonia. Ullmann's encyclopedia of industrial chemistry.

[3] Biegler, L. T. (1987). Process flow sheet optimization: recent results and future directions.

[4] Biegler, L. T., Grossmann, I. E., \& Westerberg, A. W. (1997). Systematic methods for chemical process design.

[5] Bland. (2015) Optimization of an ammonia synthesis loop.

[6] Gaines, L. D., \& Gaddy, J. L. (1976) Process optimization by flow sheet simulation. Industrial \& Engineering Chemistry Process Design and Development, 15(1), 206211.

[7] McKenzie, F. C., \& Williams, J. (2015). Sustainable food production: constraints, challenges and choices by 2050. Food Security, 7(2), 221-233.

[8] Sotoft, L. F., Pryds, M. B., Nielsen, A. K., \& Norddahl, B. (2015). Process Simulation of Ammonia Recovery from Biogas Digestate by Air Stripping with Reduced Chemical Consumption. In Computer Aided Chemical Engineering (Vol. 37, pp. 2465-2470). Elsevier 


\begin{tabular}{|l|c|}
\hline Proceeding of the $9^{\text {th }}$ ICEE Conference 3-5 April 2018 & CEA \\
Military Technical College \\
Kobry El-Kobbah, \\
Cairo, Egypt
\end{tabular}

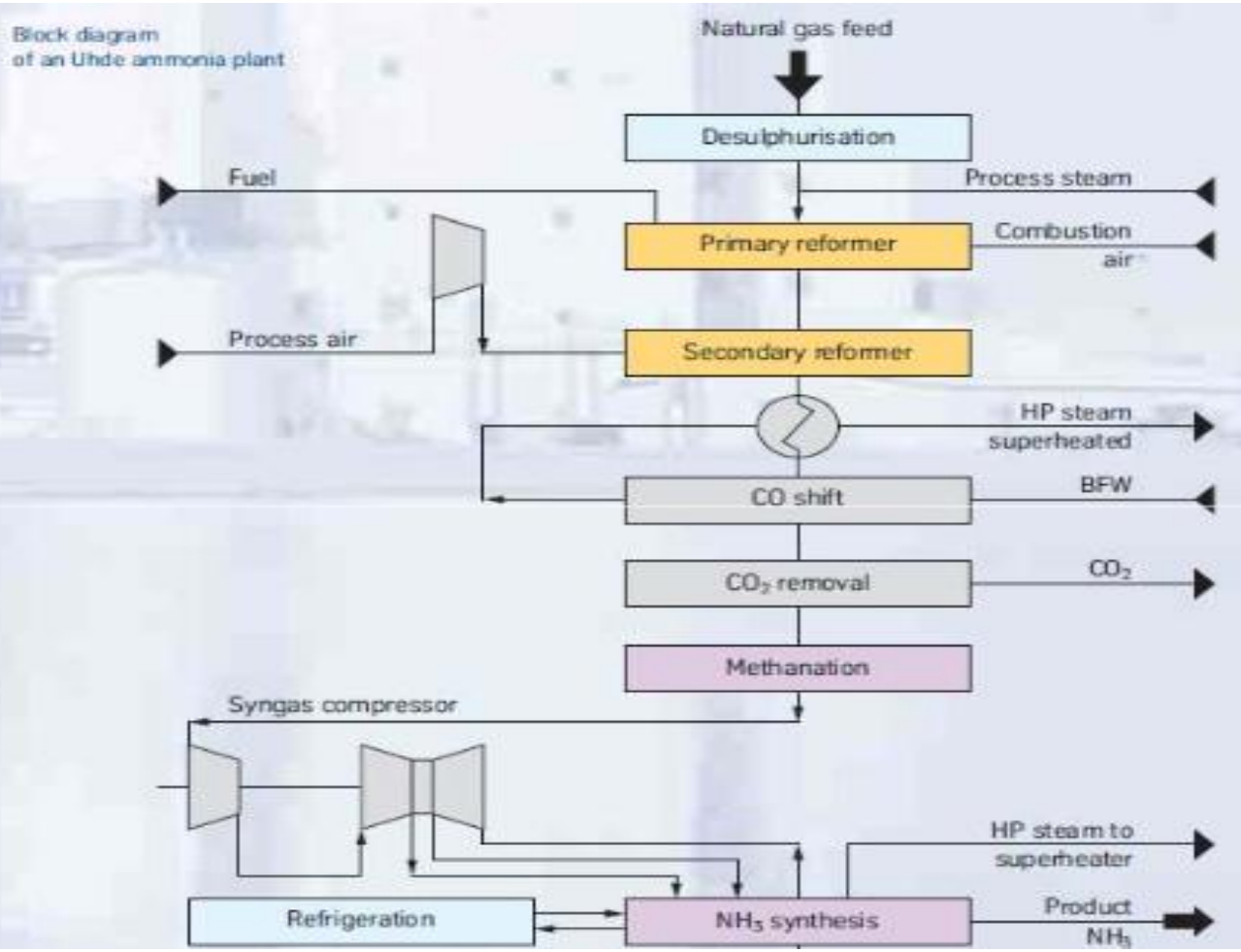

Figure (1) block diagram of ammonia plant

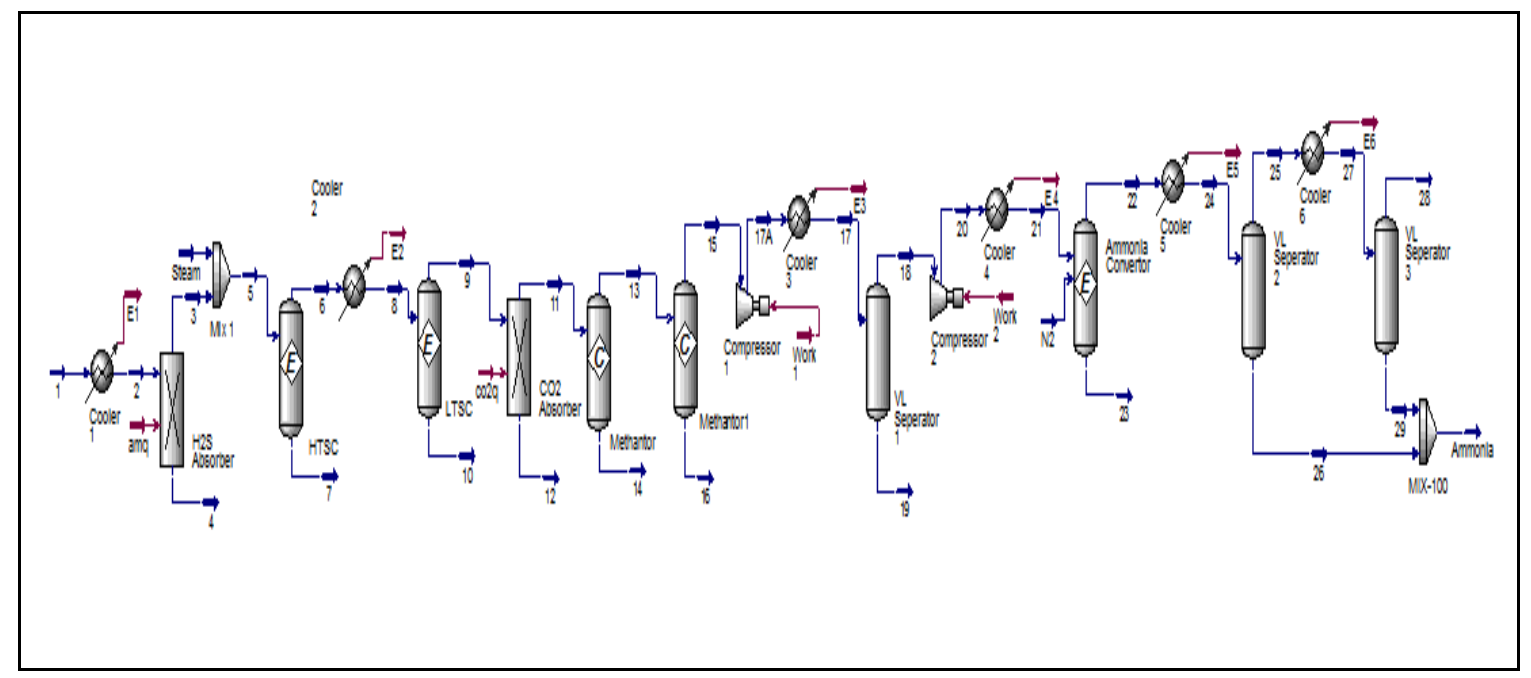

Figure (2) Hysys Process Flow diagram of ammonia synthesis 


\begin{tabular}{|c|c|}
\hline Proceeding of the $9^{\text {th }}$ ICEE Conference 3-5 April 2018 & CEA \\
Military Technical College \\
Kobry El-Kobbah, \\
Cairo, Egypt
\end{tabular}

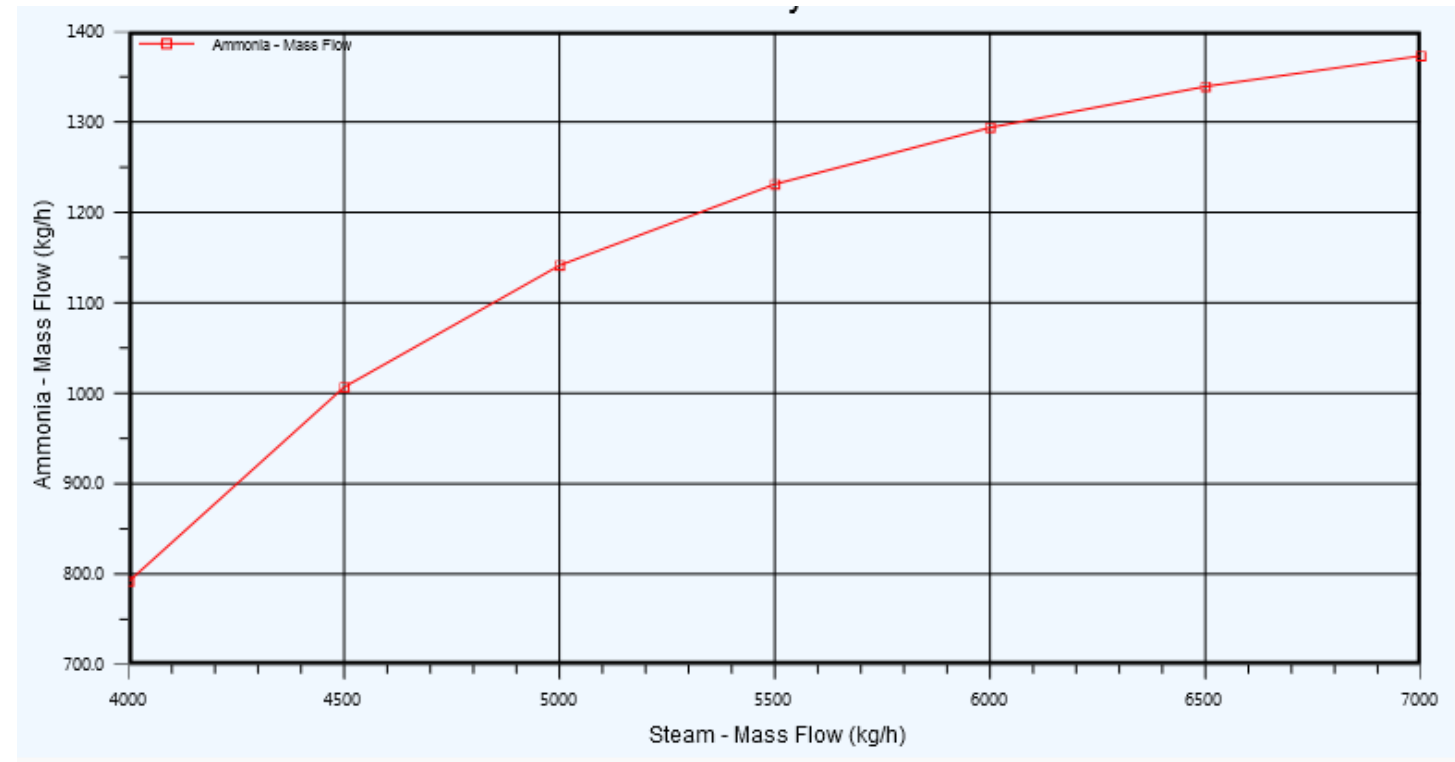

Figure (3): Mass flow rate of steam vs. Mass flow rate of ammonia

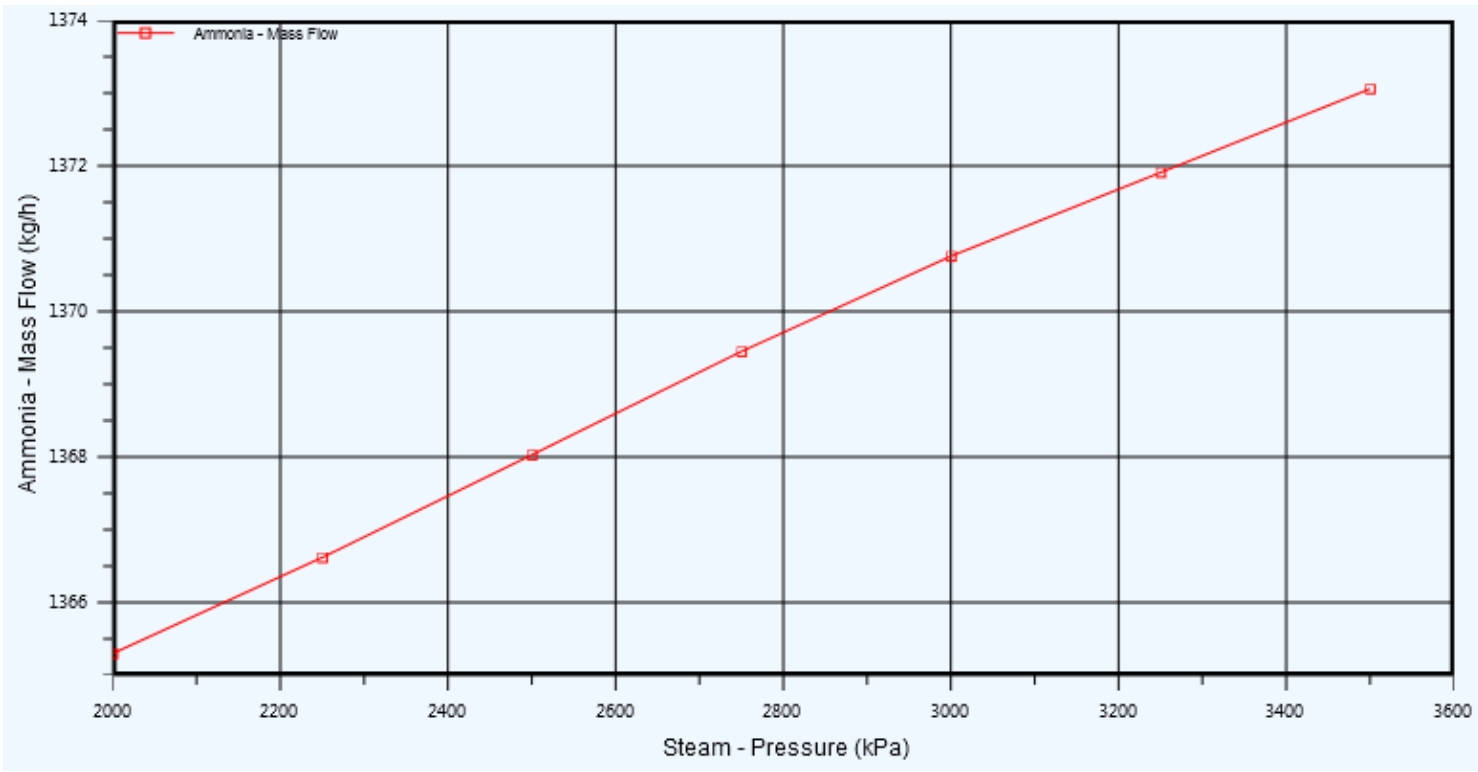

Figure (4): pressure of steam vs. Mass flow rate of ammonia 


\begin{tabular}{|c|c|c|}
\hline Proceeding of the $9^{\text {th }}$ ICEE Conference 3-5 April 2018 & CEA \\
Military Technical College \\
Kobry El-Kobbah, \\
Cairo, Egypt
\end{tabular}

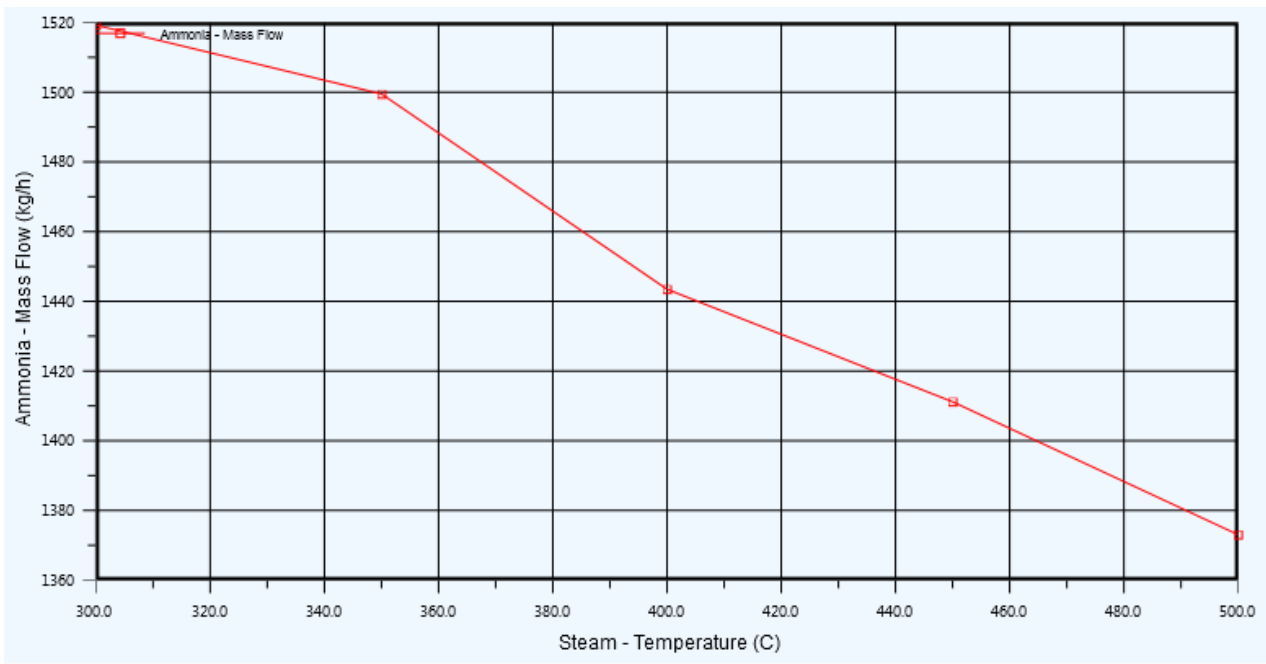

Figure (5): temperature of steam vs. Mass flow rate of ammonia

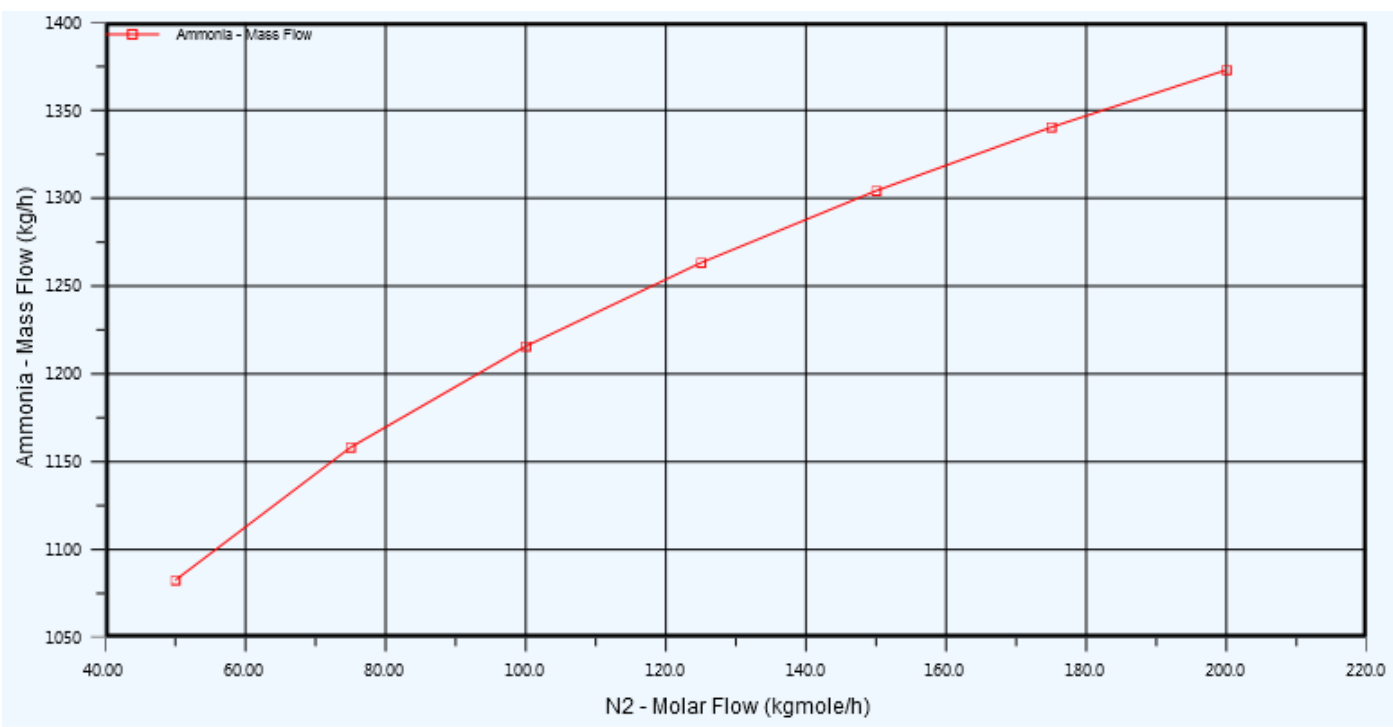

Figure (6): Mass flow rate of Nitrogen vs Mass flow rate of ammonia 
Military Technical College

Kobry El-Kobbah,

Cairo, Egypt

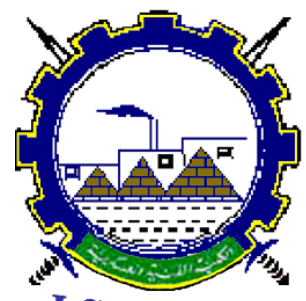

I.C.E.E.2018 $9^{\text {th }}$ International Conference on

Chemical \& Environmental

Engineering

3-5 April 2018

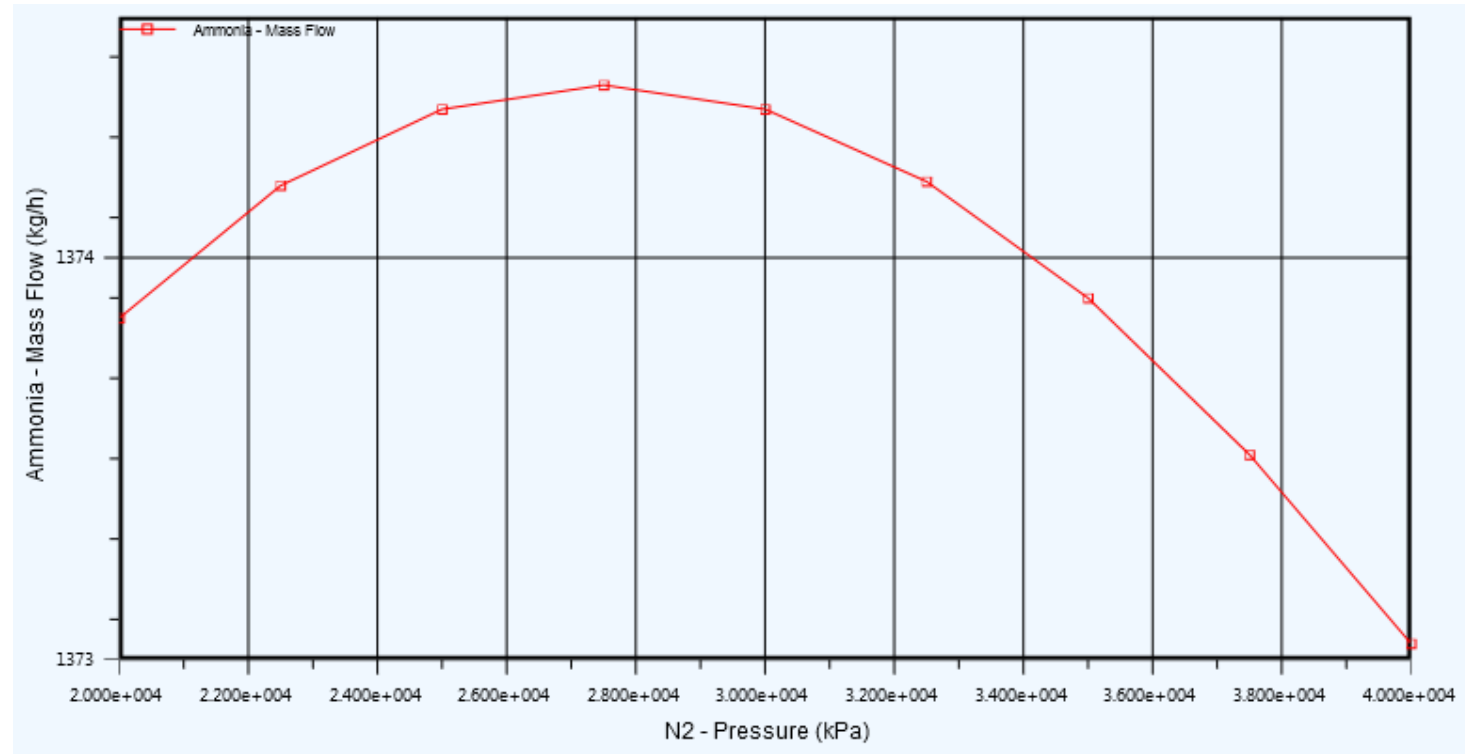

Figure (7): Pressure of Nitrogen vs. Mass flow rate of produced ammonia.

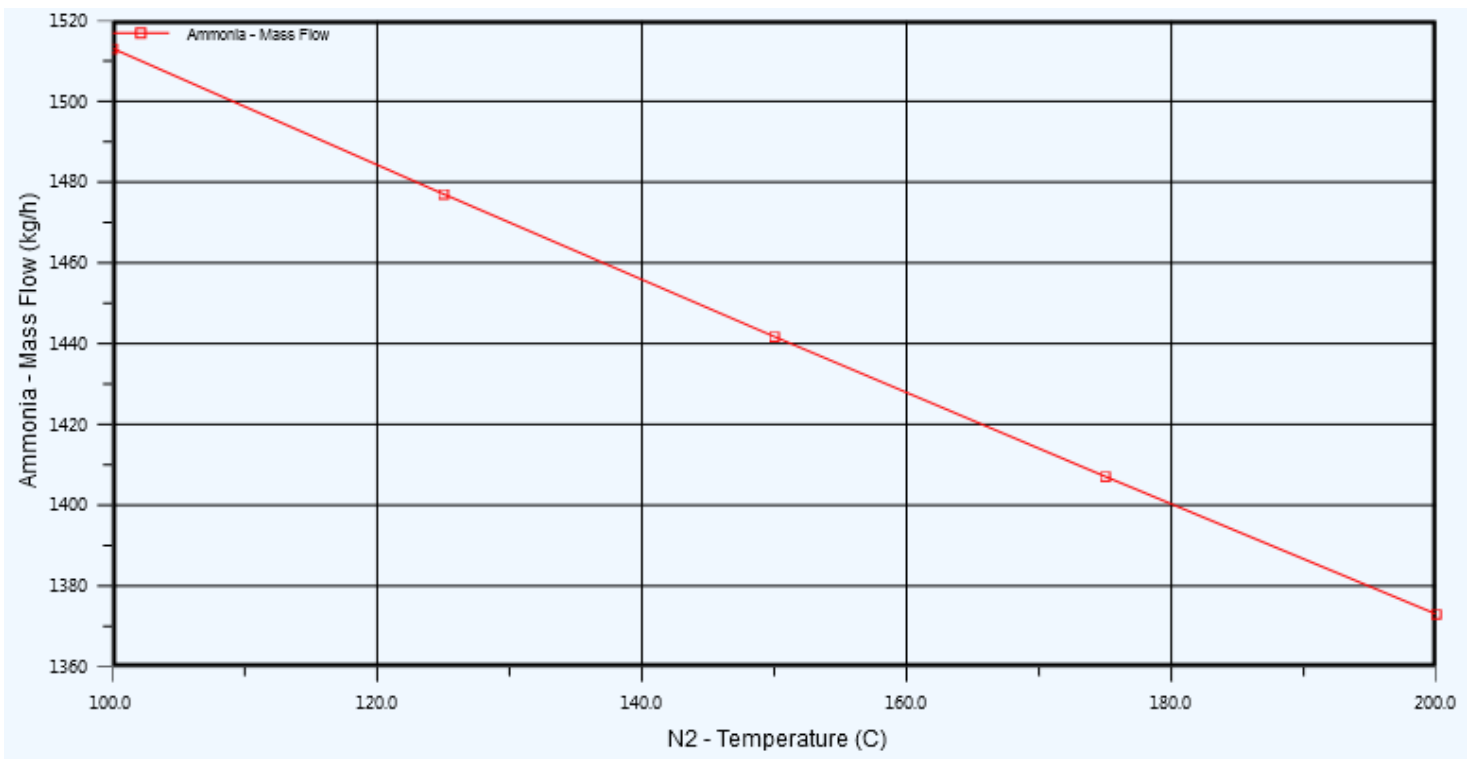

Figure (8): Temperature of Nitrogen vs. Mass flow rate of produced ammonia 


\begin{tabular}{|l|l|}
\hline Proceeding of the $9^{\text {th }}$ ICEE Conference 3-5 April 2018 & CEA \\
\hline
\end{tabular}

Military Technical College

Kobry El-Kobbah,

Cairo, Egypt

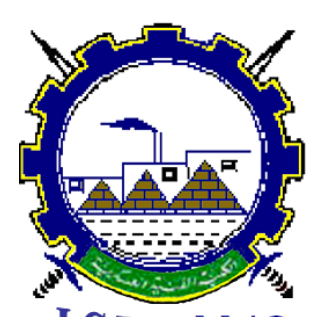

I.C.E.E.2018 $9^{\text {th }}$ International Conference on

Chemical \& Environmental

Engineering

3-5 April 2018

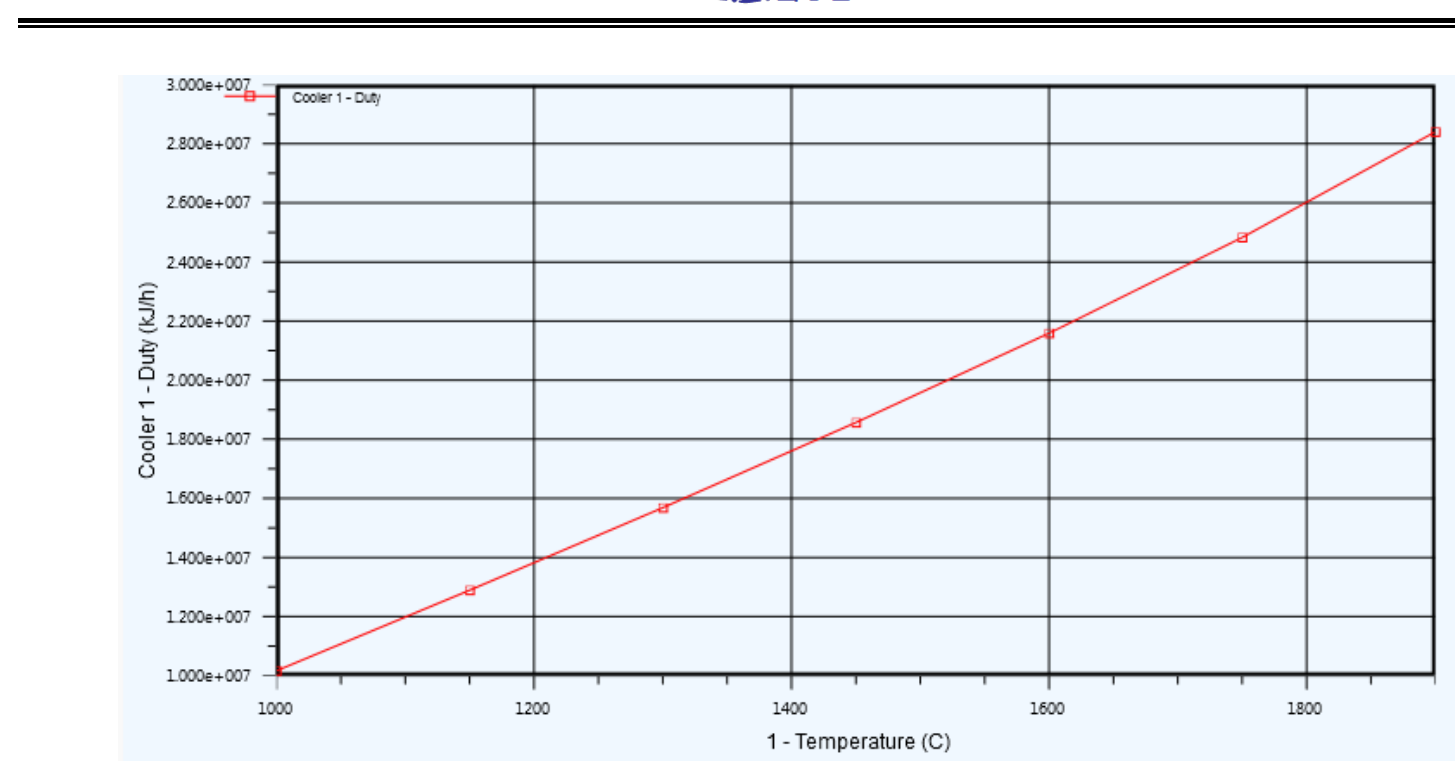

Figure (9): Temperature of stream (1) vs. the duty of cooler (1). 